\title{
A Study of Perceived Organizational Justice, Trust, and Organisational Citizenship Behaviour
}

\author{
${ }^{1}$ Dr.Richa Banerjee, ${ }^{2}$ Dr.Subeer Banerjee \\ ${ }^{l}$ Assistant Professor, Prestige Institute of Management, Gwalior (M.P.), India \\ ${ }^{2}$ Assistant professor, Maharaja Institute of Management and IT, Gwalior(M.P.),India
}

\begin{abstract}
The present organizations in which cut throat competition is there among employees, organizational justice and trust become more important to develop organizational citizenship behavior. organisation citizenship behavior is voluntary behavior on the part of employee which does not bring any reward to them. An employee who feels like citizen of organization does something extra for organization and coworkers which is not described in job description. Many previous researches proved impact of trust on organizational citizenship behavior and impact of organizational justice on organizational citizenship behavior. This study attempts to find out impact of trust and justice on OCB separately as well as combined impact of both the variables on OCB in service industry of Gwalior (MP, India).various statistical tools like reliability analysis and regression analysis was applied to the gathered data to fulfill the objective of the study.
\end{abstract}

Key words: organizational justice, trust, organizational citizenship behavior, reliability, regression

\section{Organizational Justice}

In present context to deal every employee with fairness, providing equal opportunities, fair wages, fair and equitable approach to information and resources etc. has become of vital importance and a term which is given to fairness in organization is organizational justice. Organizational justice has been defined as the study of the concerns about fairness in the workplace like distribution of resources, fairness of decision-making procedures, and interpersonal treatment. Organizational Justice is essentially the perception of fairness and the reaction to those perceptions in the organisational context (Greenberg, 1987). It is broken down into three areas namely: distributive, procedural and interactional justice. Distributive justice, based on equity theory, refers to the perceived fairness regarding a person's perceived input versus the reward obtained (Adams, 1963). These are content (perceptions of distributive justice within the agency), process (procedural justice) and interactions (interpersonal and informational justice) (Greenberg, 1990) An individual's perception of distributive justice is related to how they feel they should be rewarded based on their level of productivity (pay, workload and benefits), higher perceptions may result in more positive attitudes towards the organisation (Chi and Han, 2008). Procedural justice refers to fairness by which decisions or outcome distributions are made, including the inclusion of a system for employee complaints (Clay-Warner et al., 2005; Simpson \& Kaminski, 2007). Finally, interpersonal and informational justice focuses on the human or social aspects such as the quality of treatment and behaviors between those in charge of allocating resources and the recipients (Chou, 2009). The term 'organisational justice' was first used by French in 1964 to refer in general to fairness issues in personnel management (French 1964), but it was Greenberg who first used the term specifically to refer to people's perceptions of fairness (Greenberg 1987).

\section{Distributive Justice}

Distributive justice is the perceived fairness of outcome distributions (Adams 1965; Leventhal 1976a). According to distributive justice research, a distribution is perceived to be fair if it is consistent with chosen norms of allocation. Early contributions focused on the equity norm of allocation, according to which outcomes should be distributed in proportion to merit (Homans 1961). Adams (1965) formalised equity in exchange relationships in his "equity theory" which posits that people compare their own input/outcome ratio to the other person's input/outcome ratio. If the ratios are unequal, then inequity is perceived. A person who perceives their own ratio to be lower than the "just ratio" is predicted to feel guilty; a person who perceives their own ratio to be higher is predicted to feel angry. People strive to remove the unpleasant state of inequity,either by altering inputs or outcomes, by cognitive distortion of inputs or outcomes, by leaving the exchange relationship, by altering the other's inputs or outcomes, or by changing the object of comparison. Subsequently, other distribution rules such as equality and need were introduced (e.g., Deutsch 1975; Leventhal 1976b; Sampson 1975). The equality rule defines the same outcome for all as fair. A need-based allocation distributes outcomes proportionate to the need of individuals. Lerner (1974) pointed out that different types of relationships call for different rules of distribution. The rule of equality is often used among friends, while the rule of need is more likely to be used in close relationships, where people identify and have empathy with each other. Individual 
rules may be more or less influential depending on context, goals and motives, and a number of rules could be considered simultaneously (Leventhal 1976a).

\section{Procedural Justice}

The second category of fairness is procedural justice, which refers to the fairness of the process that leads to outcomes. This dimension was introduced by Thibaut and Walker (1975), procedural justice was transferred into a non-legal context by Leventhal (1980). Leventhal identified six criteria of perceived procedural fairness. Typically,procedures are perceived to be "fair" when they are consistent across people and over time, free of bias, accurate (relying on good information), contain mechanisms for correcting wrong decisions, adhere to prevalent conceptions of morality, and are "representative" (i.e.,take into account opinions of all groups affected), which implies process control and decision control.

\section{Interactional Justice}

Interactional justice was introduced by Bies and colleagues (Bies and Moag 1986; Bies and Shapiro 1987; Bies and Shapiro 1988; Bies et al.1988), they said that people also judge the fairness of the interpersonal treatment they receive when procedures and rules of organisation are enacted (Bies and Moag, 1986).there are four central concerns of interactional fairness: truthfulness (honesty),justification (explanations), respect (politeness) and propriety (no prejudicial statements or improper questions) (Bies 1987; Bies and Moag 1986). Greenberg proposed to split interactional justice into two main elements: the quality of treatment (respect and sensitivity), and explanations and information regarding decision making (Greenberg 1993).

Informational justice focuses on the amount and quality of information provided concerning procedures and outcomes (Colquitt 2001; Greenberg 1990). Clarity, adequacy and sincerity of communications regarding a decision are important antecedents of informational justice.

Interactional justice:

Interactional justice has been seen as consisting of two specific types of inter-personal treatment (Greenberg, 1990a, 1993b). The first type is named "interpersonal justice" and refers to the degree to which people are treated with politeness, dignity and respect by authorities or third parties involved in executing procedures or determining outcomes. The second type is named "informational justice" and focuses on the explanations provided by people who convey information about why procedures were used in a certain way and why outcomes were distributed in a certain manner. (Colquitt 2001, Colquitt et al 2001)

\section{Trust}

Trust in the organization is built from the employee's belief that since current organizational decisions are fair, future organizational decisions will be fair. Robinson (1996) defined trust as a person's expectations, assumptions, or beliefs about the likelihood that anothers future actions will be beneficial, favorable, or at least not deterimental to ones interests". Barber (1983) characterized trust as a set of "socially learned and socially confirmed expectations that people have of each other, of the organizations and institutions in which they live, and of the natural and moral social orders that set the fundamental understandings for their lives"

In a social context, trust has several connotations. Definitions of trust typically refer to a situation characterized by the following aspects: One party (trustor) is willing to rely on the actions of another party (trustee); the situation is directed to the future. In addition, the trustor (voluntarily or forcedly) abandons control over the actions performed by the trustee. As a consequence, the trustor is uncertain about the outcome of the other's actions; he can only develop and evaluate expectations. The trust has been categorized in to three types in organizational relationship. It is deterrence based trust which is most fragile relationships are there. This form is grounded not only in the fear of punishment for violating trust, but also in the rewards for preserving it. Trust is based on a calculation comparing the costs and benefits of creating and sustaining a relationship versus the costs and benefits of severing it. For deterrence to be an effective threat, the potential loss of a relationship must outweigh the gain created by defecting from it. There must be monitoring and reporting between the parties. The person who has been harmed must also be willing to follow through on threats of punishment.

Knowledge-based trust occurs when an individual has enough information and understanding about another person to predict that person's behavior. Accurate prediction depends on understanding, which develops from repeated interactions, communication, and building a relationship. Unlike calculus-based trust, knowledgebased trust (KBT) is founded not on control, but information. Parties cultivate knowledge of each other by gathering data, seeing each other in different contexts, and experiencing each other's range.

Identification-based trust happens when parties understand and endorse one another, and can act for each other in interpersonal transactions. This requires parties to fully internalize and harmonize with each other's desires and intentions. Certain activities enhance trust based on identification. For example, organizations and individuals can assume a common identity. They can co-locate, create joint products and goals, and share core values. 
Identification-based trust (IBT) builds on trust based on knowing and predicting another personís needs and preferences; these needs and preferences are also shared. Identification enables us to think, feel and respond like the other person.

\section{Organizational citizenship behavior}

Organizational citizenship behavior is generally conceptualized as behaviors related to the work place but are discretionary, that is, are not part of the formal organizational reward system but promote the effective functioning of the organization (Greenberg, 2005; Organ, 1988; Organ \& Konovesky, 1989; Zellars, Tepper, \& Duffy, 2002). Organ's definition of OCB includes three critical aspects that are central to this construct. First, OCBs are thought of as discretionary behaviors, which are not part of the job description, and are performed by the employee as a result of personal choice. Second, OCBs go above and beyond that which is an enforceable requirement of the job description. Finally, OCBs contribute positively to overall organizational effectiveness. According to Organ (1988), organizational citizenship behavior has five components: altruism, conscientiousness, civic virtue, courtesy, and sportsmanship.

The examination of the literature indicates that almost 7 potentially different forms of OCB have been identified, which may be grouped in seven common themes:

(1) Helping behavior involves voluntarily helping others with, or preventing the occurrence of, Work-related problems.

(2) Sportsmanship represents the willingness to face with tolerance and "fair play" the inevitable Inconveniences and impositions of work without complaining and protest.

(3) Organizational loyalty means promoting the organization to outsiders, protecting it against External threats, endorsing organizational objectives, and remaining committed to the Organization even when adverse conditions are experienced.

(4) Organizational compliance is the most controversial dimension, given its quasi in-role nature, Referring to the employee's internalization and acceptance of the organization's rules and

Procedures, which leads to a scrupulous adherence to them, even if no one is observing or monitoring compliance.

(5) Individual initiative dimension includes voluntary creativity and innovation behaviors, aiming at the improvement of individual and/or organizational performance, taking the initiative to solve problems before asking others (e.g., supervisor) to solve them, persisting with extra effort to perform the job, volunteering to assume extra responsibilities, and encouraging fellow coworkers to do the same.

(6) Civic virtue represents the willingness to participate actively in the organization governance, to monitor for threats and search for opportunities in favor of the organization, and to look out for the best interests of the organization, even with personal sacrifice. Illustrative behaviors are attending meetings even when not required, expressing one's opinion about the strategy and Policies the organization ought to pursue, keeping up with changes in the industry that may affect the organization, and reporting suspicious activities that can damage the organization.

(7) Self development refers to the voluntary engagement of employees in self-promoting Knowledge, skills and abilities, in order to expand the range of contributions to the organization.

\section{Literature review}

Trust enables cooperative behavior, reduces conflict, and decreases transaction costs at work (Rousseau et al., 1998). It has been demonstrated to be an important predictor of certain organizational outcomes such as organizational commitment (Cook and Wall, 1980) and organizational citizenship behavior (Konovsky and Pugh, 1994, Van Dyne et al., 2000). Organizational justice, which includes distributive justice, procedural justice and interactional justice, has been found to be related to employees' commitment and trust in organization (Alexander and Ruderman, 1987; Cropanzano and Folger, 1991; Sweeney and McFarlin, 1993).

Researchers have shown that distributive justice does not significantly impact on trust (Konovsky and Pugh, 1994). However, Kumar, Scheer, and Steenkamp (1995) found that both procedural justice and distributive justice contribute to relationship quality, and procedural justice appears to be a more important determinant of trust. Tyler and Lind (1990) reported that both procedural justice and distributive justice affect trust, but the former holds a stronger relationship.OCB can be defined and operationalized in various ways (Graham, 1991; Organ, 1988. According to Meyer and Allen (1997), OCB typically include such things as "providing extra help to coworkers, volunteering for special work activities, being particularly considerate of coworkers and customers, being on time, and making suggestions when problems arise". The linkage between trust in organization and OCB has been examined ( Konovsky and Pugh, 1994; Podsakoff, MacKenzie, Moorman and Fetter, 1990). According to Konovsky and Pugh (1994), trust is a manifestation of social exchange, and social exchange accounts for OCB by encouraging employees to behave in ways that are not strictly mandated by their employers (Rousseau and Parks, 1993). Employees with higher trust in their 
organization are likely to display more OCB, regardless of the types of organization. A subordinate will have a higher level of trust in their supervisor when they perceived more interactional justice, organizations should foster the development of close relationship between supervisor and their subordinates. With a high quality of interpersonal interaction and interpersonal trust in the workplace,Yui-tim Wong In this study, we investigate the relationships of perceived organizational justice, trust, and organizational citizenship behavior (OCB) among Chinese workers in joint ventures (JVs) and state-owned enterprises .Organizational justice is considered a fundamental requirement for the effective functioning of organizations. The common findings in organizational settings are that procedures/policies enhance the perceived fairness of the outcomes they produce, such as organizational commitment, trust, job satisfaction and organizational citizenship behaviour ( Maria Lazzarin,2007) . Trust enables cooperative behavior, reduces conflict, and decreases transaction costs at work (Rousseau et al., 1998). It has been demonstrated to be an important predictor of certain organizational outcomes such as organizational commitment (Cook and Wall, 1980) and organizational citizenship behavior (Konovsky and Pugh, 1994, Van Dyne et al., 2000). Organizational justice, which includes distributive justice, procedural justice and interactional justice, has been found to be related to employees' commitment and trust in organization (Alexander and Ruderman, 1987; Cropanzano and Folger, 1991; Sweeney and McFarlin, 1993).

Alexander and Ruder man (1987) found that trust in management showed substantial unique effects of procedural justice. Procedural justice has been found to affect the evaluation of the organization and its authorities (Cropanzano and Folger, 1991; Sweeney and McFarlin, 1993), and thus it would have strong impact on trust in organization. Arguably, employees will have a high level of trust in organization when they are guaranteed fair procedural treatment. Sharon M. Hopkins Bart L. Weathington, examined perceptions of distributive justice, procedural justice, trust, organizational conimitmetit, Satisfaction, and turnover intentions among survivors it's an organization that had recctitly completed an organizational downsizing. Results suggested that trust partially mediated the relationship between distributive justice and both organizational .satisfaction and affective commitment. Additionally, the relationship between procedural justice and turnover intentions was mediated by trust perceptions.

Recent research suggests that organizational justice and trust are two variables related to each other (Hoy \& Tarter, 2004). A number of researchers have heighted the relationship between organizational justice and trust. Teachers trust towards the organization is considered as an important indicator of justice in work place (Lewicki, Wiethoff, \& Tomlinson, 2005). According to Geist and Hoy (2003), teacher's trust towards the organization provides a various advantages include, encourage cooperatives, reduces conflict and dissatisfaction and also increases teachers self confidence. A number of researchers and scholars (e.g. Petersen, 2008; Smith, Thomas \& Tyler, 2006) found that both justice and trust profoundly affect the effectiveness and performance of an organization. However, when a teacher feels that his/her contributions and expectations are accepted and supported by the stakeholders Within his/her organization as a result, teachers' trust towards the organization will increase (Hassan, 2002; Petersen, 2008).

\section{Organizational Justice and OCB}

Researchers suggest that people react positively to procedural and interactional justice due to various reasons, but mainly:

i) People believe that if procedures and interactions are fair, it will increase their probability of getting outcomes that are favourable and fair in the future (Lind \&Tyler, 1988; Cropanzano \& Greenberg, 1997). This perspective is called instrumental (or self-interest model). Therefore,

people are willing to engage in extra-role behaviours even if at present there is distributive injustice;

ii) When people feel that they are treated with respect and dignity and valued by the group that they belong to, they are prone to go beyond their functional duties (Tyler, 1994; Tyler et al, 1996; Tyler and Degoey, 1996).

This perspective is derived from the group value model also known as the relational model. Trust either in the procedures and superiors/authorities is the basis for the sentiments,attitudes and behaviours to occur. It is trust that greatly determines the relationships between perceptions of justice and OCB (Brockner and Siegel, 1996, Konovsky \& Pugh 1994) It shows that fostering procedural justice also results in an enhancement of trust. These processes result in strengthening trust in the leader-subordinate relationship and the attendant tendency on the part of subordinates to engage in extra effort and self-sacrificing behaviors which would show up in the form of citizenship behavior. These conclusions are consistent with the findings of Moorman et al. (1993) that satisfaction, commitment, and organizational citizenship behavior all emerge from fairness of procedures which in turn influence trust.( Oliver E. Ngodo).

\section{Research Methodologies}

The study conducted was causal in nature. The cause and effect relationship was tried to find out between dependent variable organizational citizenship behavior and independent variables perceived 
organizational justice and trust. The purpose of this study is to examine relationships among perceived organizational justice, trust and OCB. To find out impact of justice, trust on organizational citizenship behavior.

The employees from private banking sector were taken as sample to participate in research and the sample size was 184 employees chosen with the help of convenience technique. Primary data will be collected with the help of questionnaire. the scale for trust were having 10 item, the scale used to measure justice was having 10 items and the scale for measuring organizational citizenship behavior was having 14 items.

The data gathered will be analyses using SPSS software. Reliability analysis and regression analysis was used to analyze the gathered data.

The data analysis procedures chosen for this research were based on their applicability to the causal nature of the research design. Reliability analysis checked the reliability of the responses in which item to total and inter item correlation was checked. The items having more than 0.5 inter item correlation value was to be dropped and the item having less than 0.4 item to total correlation value was also to be dropped.

In terms of the linear and multiple regression analyses, the value of $\mathrm{R}^{2}$, adjusted $R^{2}$ was used to determine the proportion of the total variance of the dependent variable (OCB) that is explained by the independent variables (Perceived organizational justice and trust). The F-test was used to test whether there was a significant relationship and can regression $(p \leq 0.05)$ between the independent and dependent variables.

\section{Reliability analysis}

\section{Results and discussion}

Reliability is the consistency of the measurement, or the degree to which an instrument measures the same way each time it is used under the same condition with the same subjects. To measure reliability of the three variables cronbach's alpha reliability is calculated using SPSS software.

Table 1: showing reliability values of variables

\begin{tabular}{|l|r|r|}
\hline Variable & Reliability value & No of items \\
\hline Perceived organizational justice & .847 & 10 \\
\hline Trust & .901 & 10 \\
\hline Organizational citizenship behavior & .828 & 14 \\
\hline
\end{tabular}

\section{Regression analysis}

In regression analysis the measure of $\mathrm{R}^{2}$ is considered as measure of association, it represents the percentage of variance in the values of $\mathrm{Y}$ (dependent variable) is explained by value of $\mathrm{X}$ (independent variable). It varies from 0.0 to 1 . In this test of regression $\mathrm{F}$ is test for statistical significance. This tests the hypothesis that the predictor (independent variable) shows no relationship to Y (independent variable).

The table below is showing value of $r$ square to be 0.344 which depicts that the variance in organizational citizenship behavior can be explained upto $34.4 \%$ by independent variable that is trust.

Table 2

\begin{tabular}{|l|r|r|r|r|}
\hline Model & R & R square & Adjusted R square & \multicolumn{2}{|c|}{ Std.error } \\
\hline 1 & $.586^{\mathrm{a}}$ & .344 & .338 & 6.32476 \\
\hline
\end{tabular}

In the table the value of $\mathrm{F}=64.381$ is significant at 0.00 significant which denotes that null hypothesis of this test that there is no relationship between two variables is rejected and hence there is relationship between dependent OCB and independent variable Trust.

Table 3

\begin{tabular}{|ll|r|r|r|r|r|}
\hline Model & Sum of Squares & Df & Mean Square & F & Sig. \\
\hline 1 & Regression & 2575.394 & 1 & 2575.394 & 64.381 & $.000^{\mathrm{a}}$ \\
& Residual & 4920.318 & 123 & 40.003 & & \\
& Total & 7495.712 & 124 & & & \\
\hline
\end{tabular}

a. Predictors: (Constant), trust

b. Dependent Variable: OCB

Table 4 Coefficients

\begin{tabular}{|c|c|c|c|c|c|}
\hline \multirow[t]{2}{*}{ Model } & \multicolumn{2}{|c|}{ Unstandardized Coefficients } & \multirow{2}{*}{$\begin{array}{c}\text { Standardized } \\
\text { Coefficients } \\
\text { Beta }\end{array}$} & \multirow[b]{2}{*}{$\mathrm{t}$} & \multirow[b]{2}{*}{ Sig. } \\
\hline & $\mathrm{B}$ & Std. Error & & & \\
\hline $\begin{array}{ll}1 & (\text { Constant }) \\
& \text { trust } \\
\end{array}$ & $\begin{array}{r}24.989 \\
.617\end{array}$ & $\begin{array}{r}3.051 \\
.077\end{array}$ & .586 & $\begin{array}{l}8.190 \\
8.024\end{array}$ & $\begin{array}{l}.000 \\
.000\end{array}$ \\
\hline
\end{tabular}

a. Dependent Variable: OCB 
Dependant Variable: OCB

$\mathrm{Y}=\mathrm{a}+\mathrm{bx}$

$\mathrm{Y}=24.989+(0.617) \mathrm{x}$

$\mathrm{X}=$ Trust (independent variable)

$\mathrm{Y}=$ Organizational Citizenship Behavior (dependent variable)

The linear regression was applied between "Psychological Contract" (independent variable) and "Organizational Citizenship Behavior" (dependent variable). The result of regression indicates that, as the value of $t$ is significant at $0.00 \%$ level of significance so null hypothesis is rejected. Hence we can say that there is a significant impact of Trust on organizational citizenship behavior.

\section{Regression analysis of organizational Justice and OCB}

The table below is showing value of $r$ square to be 0.210 which depicts that the variance in organizational citizenship behavior can be explained upto $21 \%$ by independent variable that is trust.

Table 5

\begin{tabular}{|c|c|c|c|c|}
\hline Model & $\mathrm{R}$ & r square & Adjusted r square & Std.error \\
\hline 1 & $.458^{\mathrm{a}}$ & .210 & .203 & 6.93887 \\
\hline
\end{tabular}

In the table the value of $\mathrm{F}=32.681$ is significant at 0.00 significant which denotes that null hypothesis of this test that there is no relationship between two variables is rejected and hence there is relationship between dependent OCB and independent variable justice.

Table 6

\begin{tabular}{|ll|r|r|r|r|r|}
\hline Model & & Sum of Squares & Df & Mean Square & \multicolumn{1}{c|}{ F } & \multicolumn{1}{c|}{ Sig. } \\
\hline 1 & Regression & 1573.516 & 1 & 1573.516 & 32.681 & $.000^{\mathrm{a}}$ \\
& Residual & 5922.196 & 123 & 48.148 & & \\
& Total & 7495.712 & 124 & & & \\
\hline
\end{tabular}

a. Predictors: (Constant), justice

b. Dependent Variable: OCB

Table 7

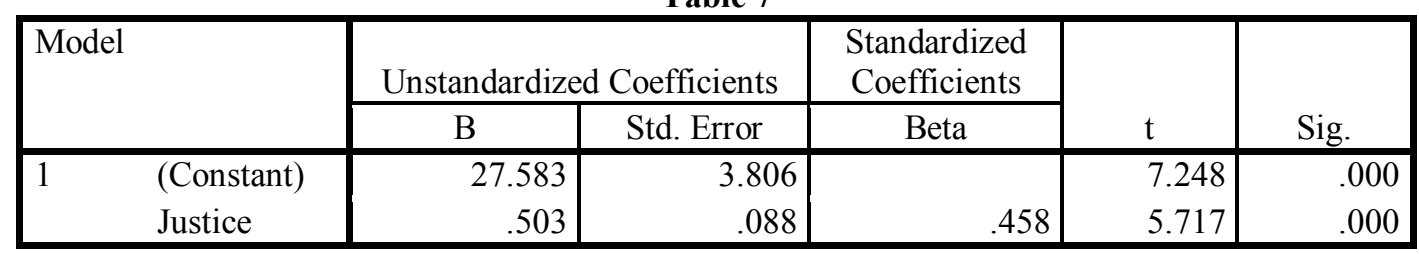

a. Dependent Variable: OCB

Dependant Variable: OCB

$\mathrm{Y}=\mathrm{a}+\mathrm{bx}$

$\mathrm{Y}=27.583+(0.503) \mathrm{x}$

$\mathrm{X}=$ Organizational Justice (Independent Variable)

$\mathrm{Y}=$ Organizational Citizenship Behavior (dependent variable)

The linear regression was applied between "organizational justice" (independent variable) and "Organizational Citizenship Behavior" (dependent variable). The result of regression indicates that, as the value of $t$ is significant at $0.00 \%$ level of significance so null hypothesis is rejected. Hence we can say that there is a significant impact of Organizational Justice on organizational citizenship behavior.

\section{Impact of Trust and organizational justice on OCB}

The $r$ square value of regression analysis of trust and organizational justice on OCB in Table 8 states that $34.6 \%$ of variance in OCB can be described with the help of trust and organizational justice.

Table 8

\begin{tabular}{|l|l|r|r|r|}
\hline Model & R & r square & Adjusted r square & Std.error \\
\hline 1 & $.588^{\text {a }}$ & .346 & .335 & 6.33928 \\
\hline
\end{tabular}

In the table 9 the value of $\mathrm{F}=32.262$ is significant at 0.00 significant which denotes that null hypothesis of this test that there is no relationship between the variables is rejected and hence there is relationship between dependent OCB and independent variable organizational justice and trust. 
Table 9

\begin{tabular}{|ll|r|r|r|r|r|}
\hline Model & & Sum of Squares & Df & Mean Square & F & \multicolumn{1}{c|}{ Sig. } \\
\hline 1 & Regression & 2592.967 & 2 & 1296.483 & 32.262 & $.000^{\mathrm{a}}$ \\
& Residual & 4902.745 & 122 & 40.186 & & \\
& Total & 7495.712 & 124 & & & \\
\hline
\end{tabular}

a. Predictors: (Constant), trust, justice

b. Dependent Variable: OCB

Table 10

\begin{tabular}{|c|c|c|c|c|c|c|c|}
\hline \multirow[t]{2}{*}{ Model } & \multicolumn{2}{|c|}{$\begin{array}{c}\text { Unstandardized } \\
\text { Coefficients }\end{array}$} & \multirow{2}{*}{$\begin{array}{c}\text { Standardize } \\
\mathrm{d} \\
\text { Coefficient } \\
\mathrm{s} \\
\\
\text { Beta }\end{array}$} & \multirow[b]{2}{*}{$\mathrm{T}$} & \multirow[b]{2}{*}{ Sig. } & \multicolumn{2}{|c|}{$\begin{array}{c}\text { Collinearity } \\
\text { Statistics }\end{array}$} \\
\hline & B & Std. Error & & & & $\begin{array}{c}\text { Toleran } \\
\text { ce }\end{array}$ & VIF \\
\hline $\begin{array}{ll}1 & \text { (Constan } \\
\text { t) }\end{array}$ & 23.788 & 3.558 & & 6.686 & .000 & & \\
\hline trust & .077 & .117 & .070 & .661 & .510 & .475 & 2.106 \\
\hline justice & .564 & .112 & .535 & 5.037 & .000 & .475 & 2.106 \\
\hline
\end{tabular}

a. Dependent Variable: OCB

$\mathrm{Y}=\mathrm{a}+\mathrm{bx}_{1}+\mathrm{bx}_{2}$

$\mathrm{Y}=27.583+(0.077) \mathrm{x}_{1}+(0.564) \mathrm{x}_{2}$

$\mathrm{X}_{1}=$ Trust (Independent variable)

$\mathrm{X}_{2}=$ Organizational Justice (Independent Variable)

$\mathrm{Y}=$ Organizational Citizenship Behavior (dependent variable)

The $\mathrm{T}$ value predicts that the combined impact of both the independent variable on the independent variable is not too significant as the $t$ value of trust is significant on 0.510 level of significance which is much higher than the acceptable significant value i.e 0.05 .at the same time the t value justice is significant at 0.00 significant level which shows that there is significant impact of independent variable on dependent variable. This table predicts that the impact of organization justice is moderated because of impact of trust.

The $\mathrm{F}$ value as well as $\mathrm{R}$ square value also signifies that there is significant impact of independent variables on dependent variables. So in the end on the basis of $\mathrm{R}$ square value and $\mathrm{F}$ value we can conclude that the null hypothesis is rejected that there is no significant impact of organizational justice and trust on organizational citizenship behavior.

\section{References}

[1]. Adams, J. S. (1963). Towards an understanding of inequity. Journal of Abnormal and Social Psychology, 67, 422-436.

[2]. Adams, J. S. (1965). Inequity in social exchange. In L. Berkowitz :(Ed.), Advances in experimental social psychology (Vol. 2 , pp. 267-299). New York: Academic Press.

[3]. Alexander, S., \& Ruderman, M. (1987). The role of procedural and distributive justice in organizational behaviours. Social Justice Research, 1, 177-198.

[4]. Barber, B. (1983). The logic and limits of trust. New Brunswick, NJ: Rutgers University Press.

[5]. Bies, R. J., and Moag, J. S. (1986). Interactional justice: communication criteria of fairness. in R. J. Lewicki; B. H. Sheppard, and M. H. Bazerman (Eds.) Research on Negotiations in Organizations, Vol. 1, 43-55. Greenwich, CT: JAI Press

[6]. Bies, R. J. and Shapiro, D. L. (1987). Interactional Fairness Judgements: The Influence of Causal Accounts. Social Justice Research, $1(2)$.

[7]. Bies, R. J. and Shapiro, D. L. (1988). Voice and justification: Their influence on Procedural fairness judgments. Academy of Management Journal, 31,

[8]. Cook, J., \& Wall, T. (1980). New work attitude measures of trust, organizational commitment and personal need non-fulfillment. Journal of Occupational Psychology.

[9]. Cropanzano, R., and Folger, R. (1991). Procedural justice and worker motivation. In R. M. Steers and L.W. Porter (Eds.), Motivation and Work Behavior. New York: McGraw-Hill.

[10]. Colquitt, J. A. (2001). On the dimensionality of organizational justice: A construct validation of a measure. Journal of Applied Psychology, 86, 386-400

[11]. Cropanzano, R., \& Greenberg, J. (1997). Progress in organizational justice: Tunneling through the maze. In C. L. Cooper \& I. T. Robertson (Eds.),International review of industrial and organizational psychology (pp. 317-372). New York: Wiley

[12]. Deutsch, M. (1975). Equity, equality, and need: What determines which value will be used as the basis for distributive justice? Journal of Social Issues, 31, 137-149

[13]. French, W. (1964). The Personnel Management Process: Human Resources Administration.Boston: Houghton Mifflin Company

[14]. Greenberg, J. (1990). Organizational justice: Yesterday, today, and tomorrow. Journal of Management, 16(2), 399-432.

[15]. Greenberg, J. (1993). The social side of fairness: Interpersonal and informational classes of organizational justice. In Cropanzano, R. (ed.), Justice in the workplae: Approaching fairness in human resource management (pp. 79-103). Hillsdale, NJ: Erlbaum.

[16]. Jody Clay-Warner (2006), Procedural Justice and Legitimacy: Predicting Negative Emotional Reactions to Workplace Injustice, in Shane R. Thye, Edward J. Lawler (ed.) 23 (Advances in Group Processes, Volume 23), Emerald Group Publishing Limited, pp.207227

[17]. Konovsky, M. A., \& Pugh, S. D. (1994). Citizenship behavior and social exchange. Academy of Management Journal, 37 
[18]. Leventhal, G. S. (1976). The distribution of rewards and resources in groups and organizations. In L. Berkowitz \& W. Walster (Eds.), Advances in experimental social psychology(Vol. 9, pp. 91-131). New York: Academic Pres

[19]. Organ, D. (1988). Organizational citizenship behavior: The good soldier syndrome.Lexington, MA: Lexington Books

[20]. Oliver E. Ngodo organizational (2008), International Journal of Leadership Studies, Vol. 4 Iss. 1, 2008, ISSN 1554-3145

[21]. Maria Lazzarin, Developmental paper prepared for the 13th IFPSM Summer School on Advanced http://www.ifpsm.org/sites/default/files/3-exploring-organisational-justice.pdf

[22]. Greenberg, J. (1987). A taxonomy of organizational justice theories. Academy of Management Review, 12, 9-22.

[23]. Greenberg, J. (1990). Organizational justice: yesterday, today, and tomorrow. Journal of Management, 16, 399-432.

[24]. Greenberg, J., \& Folger, R. (1983). Procedural justice, participation and the fair process effect in groups and organizations. In P. B. Paulus (Ed.), Basic Group Processes (235-256). New York, NY: Springer-Verlag.

[25]. Leventhal, G. S. (1980). What should be done with equity theory? New approaches to the study of fairness in social relationship. In K. Gergen, M. Greenberg, \& R. Willis (Eds.), Social exchange: Advances in theory and research (pp. 27-55). New York: Plenum Press.

[26]. Lind, E.A. and Tyler, T.R. (1988),The Social Psychology of Procedural Justice, Plenum, New York,NY

[27]. Podsakoff, P. M., MacKenzie, S. B., Moorman, R. H., \& Fetter, R. (1990). Transformational leader behaviors and their effects on followers' trust in leader, satisfaction, and organizational citizenship behaviors. The Leadership Quarterly, 1(2), 107-142.

[28]. Sweeney, P. D., \& McFarlin, D. B. (1993). Workers' evaluations of the "ends and the "means": An examination of four models of distributive and procedural justice. Organizational Behavior and Human Decision Processes, 55, 23-40

[29]. Sharon M Hopkins, Bart L Weathington(2006), The relationships between justice perceptions, trust, and employee attitudes in a downsized organization, The Journal of Psychology Interdisciplinary and Applied .

[30]. Tyler, T. R., \& Blader, S. L. (2000). Cooperation in groups: Procedural justice, social identity, and behavioral engagement.Philadelphia: Psychology Press.

[31]. Van Dyne, L., Vandewalle, D., Kostova, T., Latham, M. E., \& Cummings, L. L. (2000). Collectivism, propensity to trust and selfesteem as predictors of organizational citizenship in a non-work setting. Journal of Organizational Behavior. 